\title{
THE SYLOID PROCESS: MORPHOMETRY AND ITS CLINICAL IMPLICATIONS IN COSTAL REGION OF ANDRAPRADESH, INDIA
}

\section{Supriya Garapati *1, Ch. Santhi ${ }^{2}$, Pentyala Suneetha ${ }^{3 .}$}

${ }^{*_{1}}$ Associate professor, Department of Anatomy, MNR Medical College, Sangareddy, Telangana, India.

${ }^{2}$ Assistant professor, Department of Anatomy, Narayana Medical College, Nellore, AndraPradhesh, India.

${ }^{3}$ professor, Department of Radiology, Narayana Medical College, Nellore, AndraPradhesh, India.

\section{ABSTRACT}

Objective: Styloid process is a slender bony projection, pointing downwards from the temporal bone. An elongated styloid process can compress the vital vessels and nerves close to it. Aim of the present study was to emphasize the styloid process morphometry and its clinical importance in study population

Materials and Methods: Styloid process of temporal bone was studied by using 52 three dimensional CT scans of both sexes.

Results: The mean length of the styloid process on right and left side was $3.15 \pm 0.52 \mathrm{~cm}, 3.03 \pm 0.55 \mathrm{~cm}$. The mean width of the right and left styloid process was $0.74 \pm 0.17 \mathrm{~cm}, 0.72 \pm 0.19 \mathrm{~cm}$. The mean medial angulation of right and left styloid process was $61.5^{\circ} \pm 8.17^{\circ}, 61.6^{\circ} \pm 6.29^{\circ}$ respectively.

Conclusion: Morphometric evaluation of the styloid process is clinically important because of its closeness to important neurovascular structures. Data obtained from the present study may useful for physicians, surgeons, radiologists, otorhinolaryngologists, dentists and for anatomists as an academic interest.

KEY WORDS: Styloid process, Eagle syndrome, elongated styloid process, CT scan

Address for Correspondence: Dr. Supriya Garapati, Associate professor, Department of Anatomy, MNR Medical College, Sangareddy, Telangana, India. E-Mail: garapati.supriya13@gmail.com

\begin{tabular}{|c|c|c|}
\hline \multicolumn{3}{|c|}{ Access this Article online } \\
\hline \multirow{2}{*}{$\begin{array}{l}\text { Quick Response code } \\
\text { DOI: } 10.16965 / \text { ijar.2017.181 }\end{array}$} & \multicolumn{2}{|c|}{$\begin{array}{l}\text { Web site: International Journal of Anatomy and Research } \\
\qquad \text { ISSN 2321-4287 } \\
\text { www.ijmhr.org/ijar.htm }\end{array}$} \\
\hline & $\begin{array}{l}\text { Received: } 13 \text { Mar } 2017 \\
\text { Peer Review: } 14 \text { Mar } 2017 \\
\text { Revised: None }\end{array}$ & $\begin{array}{l}\text { Accepted: } 15 \text { Apr } 2017 \\
\text { Published (O): } 31 \text { May } 2017 \\
\text { Published (P): } 31 \text { May } 2017\end{array}$ \\
\hline
\end{tabular}

\section{INTRODUCTION}

The styloid process (SP) is a cylindrical, long cartilaginous bone located in the temporal bone of skull. The muscles and ligaments are attached to the SP which has a role in mastication and swallowing. There are many nerves and vessels such as the carotid arteries adjacent to the SP. The SP and the stylohyoid ligament develop from the Reichert's cartilage (second pharyngeal arch). The normal SP length is approximately $20-30 \mathrm{~mm}$. Although there are cases in which it has reached $8 \mathrm{~cm}$ [1-5].

The space around the styloid process (parapharyngeal space) is divided by styloid process and muscles arising from it into prestyloid a poststyloid space. Prestyloid space is bounded medially by buccopharyngeal fascia \& laterally by medial pterygoid muscle. The glossopharyngeal nerve is situated within the prestyloid space [6] ICA, IJV, Superior Sympathetic, ganglion, CN VII, CN IX, CNX, CNXI, CNXII are 
contained within poststyloid space. The pain due to elongated styloid process is because of glossopharyngeal neuralgia, as the nerve is closely related to styloid process \& may get stretched. This condition may be unilateral or bilateral.

Angiography studies [7] have demonstrated compression of the external carotid artery produced by the calcified stylohyoid ligament due to homolateral rotation of the head.

\section{MATERIALS AND METHODS}

For the present study, computed tomography images of 52 individuals aged between 18-65 of both sexes were studied for styloid process morphometry. The CT scans were taken from the radiology department, Narayana general hospital, Nellore, A.P.

The following objectives were measured and analysed.

- Length of SP (SPL)

- SP width (SPW)

- SP's angulation

All measurements were made with anteroposterior, right lateral and left lateral views in the 3D interactive module to the end point of ossification. The length was defined as the distance between the base of the SP and the tip of the ossified SHC on the anteroposterior view. If there was a segmental ossification of the $\mathrm{SL}$, the distance was measured including the nonossified parts. The thickness of SHC ossification was defined as the distance where maximum thickness was seen. The mediolateral angle (MLA) was determined as the angle of intersection of the line connecting both bases of the SP and the longitudinal axis of the SHC on the anteroposterior view. The data were tabulated in Microsoft Excel 2007 for statistical analysis.

Fig. 1: Showing the measurement of styloid process length.

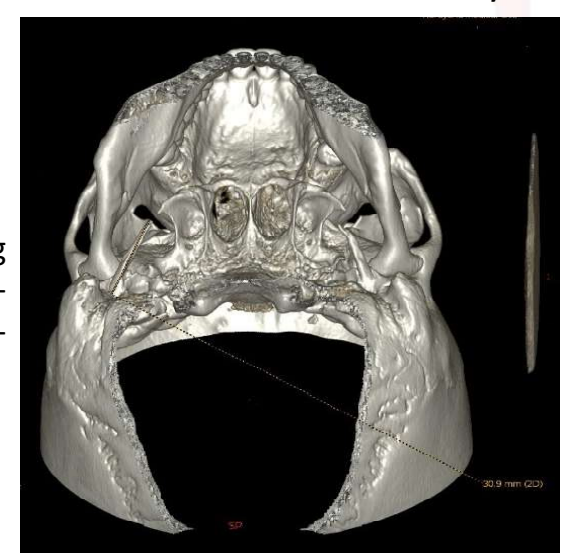

Fig. 2: Showing the measurement of styloid process width.

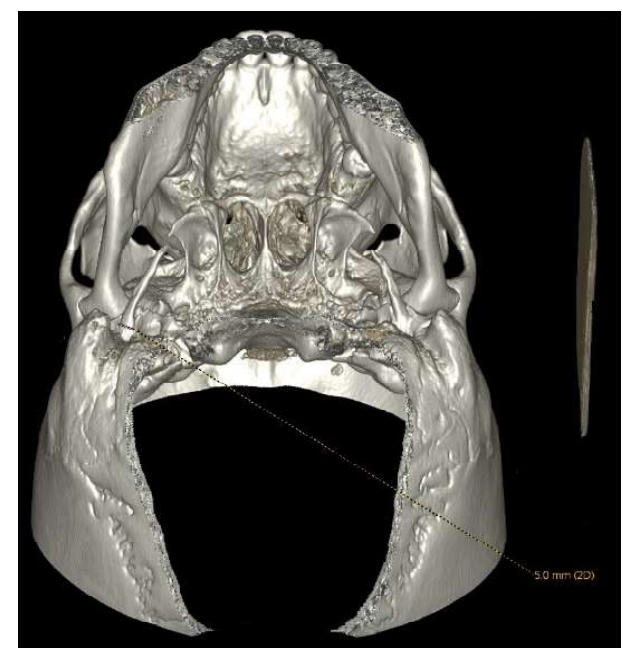

\section{RESULTS}

The mean length of the styloid process on right side was $3.15 \pm 0.52 \mathrm{~cm}$. The maximum length which was measured in this study was $4.96 \mathrm{~cm}$. The mean length of left side styloid process was $3.03 \pm 0.55 \mathrm{~cm}$, the maximum length was 4.95 $\mathrm{cm}$. The mean width of right styloid process was $0.74 \pm 0.17 \mathrm{~cm}$. The maximum width was 1.09 $\mathrm{cm})$. The mean width of styloid process on left side was $0.72 \pm 0.19 \mathrm{~cm}$. The maximum width was $1.23 \mathrm{~cm}$, the mean medial angulation of right styloid process was $61.5^{\circ} \pm 8.17^{\circ}$. The mean medial angulation of left styloid process was $61.6^{\circ} \pm 6.29^{\circ}$.

Table 1: Showing the Mean length, width and medial angulation on both sides.

\begin{tabular}{|c|c|c|c|}
\hline Side of SP & Mean length in $\mathrm{cm}$ & Mean width in $\mathrm{cm}$ & $\begin{array}{c}\text { Mean medial } \\
\text { angulation }\end{array}$ \\
\hline Right (52) & $3.15 \pm 0.52 \mathrm{~cm}$ & $0.74 \pm 0.17 \mathrm{~cm}$ & $61.5^{\circ} \pm 8.17^{\circ}$ \\
\hline Left (52) & $3.03 \pm 0.55 \mathrm{~cm}$ & $0.72 \pm 0.19 \mathrm{~cm}$ & $61.6^{\circ} \pm 6.29^{\circ}$ \\
\hline
\end{tabular}

\section{DISCUSSION}

The stylohyoid process and ligament are derived from Reichert's cartilage. During fetal development, Reichert's cartilage links the styloid bone to the hyoid bone. If these structures solidify, they can cause the pain and suffering present in Eagle's syndrome [8-11].

Eagle, who described this syndrome complex, divided it into two categories. The classical type is presented as foreign body sensation in the throat, pain in the throat and the ear ache. The other type is the styloid process compressing the carotid arterial system and presenting as 
dizziness and headache [12].

Eagle considered tonsillectomy responsible for the formation of scar tissue around the styloid apex, with consequent compression or stretching of the vascular and nervous structures contained in the retro styloid compartment (in particular, the glossopharyngeal nerve and perivascular carotid sympathetic fibers) [13] However, ES is also discovered in patients who have never been subjected to tonsillectomy.

Variations in length of the styloid process were discussed by various researchers. It has been previously reported that the normal radiographic length of styloid process was 20 to $30 \mathrm{~mm}$. whereas; Kaufman et al [14] reported that, the upper limit for the normal styloid processs as $30 \mathrm{~mm}$.

A wide range prevalence of ESP in different populations have been reported by many authors. The prevalence of elongated styloid process in the earlier studies was reported as $1 \%$ [15], 4\% [16], and $8.2 \%$ [17]. The $4 \%$ prevalence rate was observed by Eagle. The prevalence could be higher in the Iranian population, a study conducted by Ghafari-Abdollahpur [18] on 11-75-year-old patients from the Gilan province in which the prevalence was reported to be $36.4 \%$.

The prevalence of an elongated process in this study was greater than that of GhafariAbdollahpur study which was conducted over a wide range of ages. The present study showed $51.9 \%$ of prevalence of elongated styloid process on the right side, and $40 \%$ on the left side.

In most of the studies, the possibility of ESP involvement was reported equal in both sexes [19, 20, 21 and 22]. In a study done in Saudi population, the prevalence of ESP in males was $63.2 \%$ and in female it was $36.8 \%$ [23]. In contrast to these studies the present study showed the prevalence of ESP in females was $50 \%$ and in males it was $43 \%$.

By selecting an equal sample size of edentulous males and females, Bozkir [24] demonstrated that statistically there was no significant difference between the two sexes. In a study by llguy [25], the ratio of female to male involvement was reported to be 3 to 1 which was correlate with the present study.
Sachin patil et al [26] showed that anterior angulation and distance between bases and tips of styloid process decreased in elongated styloid processes. They also mentioned in their study medial angulation showed no significant change with length increase of styloid process.

Okabe et al [27] found a significant correlation between serum calcium concentration and the length of styloid process among 80 years old subjects. They noticed that, in longer styloid process, serum calcium concentration was higher.

\section{CONCLUSION}

Styloid process elongation may often be a coincidental asymptomatic radiographic finding. Therefore, proper clinical and radiographic evaluation can detect an elongated styloid process. The radiological picture of the anomalous styloid process may be beneficial for the surgeons, neurologists and radiologists in daily clinical practice. Anomalies related to styloid process may help in arriving at a correct diagnosis and help in avoiding erroneous interpretation of radiographs.

It is clearly understood that there is a lot of variation in the prevalence rate of elongated styloid process reported by different studies. In this situation, the present study would surely add the necessary data and highlights the importance of further studies on styloid process and we also emphasize that there is always a need of correlation of this data with symptomatic eagle syndrome patients.

\section{ABRREVATIONS}
3-D - Three dimentional
CT - Computer Tomography
SP - Styloid Process
SHL - Stylo Hyoid Ligament
SHC - Stylohyoid chain
ESP - Elongated Styloid Process
ES - Eagle's Syndrome
CN - Cranial Nerve
ICA - Internal Carotid Artery
IJV - Internal Jugular Vein

\section{ACKNOWLEDGEMENTS}

The authors wish to thank Dr. C. Jyothi, Associate professor, department of community 
medicine, Narayana Medical College, Nellore, A.P, India for her help in the statistical analysis.

\section{Conflicts of Interests: None}

\section{REFERENCES}

[1]. Fe'Lix Jesu' S De Paz, Cristina Rueda, Mercedes Barbosa, Mari'A Garci'A, And Juan Francisco Pastor. Biometry and statistical analysis of the styloid process, the anatomical record. 2012;295:742-747.

[2]. Scaf g, freitas dq, loffredo Ide c. diagnostic reproducibility of the elongated styloid process. J appl oral sci. 2003;11:120-4.

[3]. Zaki HS, Greco CM, Rudy TE, Kubinski JA. Elongated styloid process in a temporomandibular disorder sample: prevalence and treatment outcome. J prosthet dent. 1996;75:399-405

[4]. Bozkir MG, Boga H, Dere F. The evaluation of elongated styloid process in panoramic radiographs in edentulous patients. J med sci. 1999; 29:481-5.

[5]. Surekha d Jadhav; Sarita R Margum. Ossification of stylohyoid ligament and its clinical significance: case report. asian journal of biomedical and pharmaceutical sciences; 04 (33); 2014; 24-26.

[6]. Slavin KV. Eagle syndrome: entrapment of the glossopharyngeal nerve. case report on review of the literature J. Neurosurg 2002;97(1):216-218.

[7]. Messer EJM, Abramson AM. The styloid process syndrome. J Oral Surg.1975;33:664-667.[PubMed]

[8]. Monsour PA, Yougn WG. Variability of the styloid process and stylohyoid ligament in panoramic radiographs. Oral surg oral med oral pathol 1986; 61:522-26.

[9]. Winkler S, Sammartino FJ, monari JH. Stylohyoid syndrome. oral surg oral med oral pathol 1981;51:215-17

[10]. Keur JJ, Campbell JP, Mccarthy JF, Ralph WJ. The clinical significance of the elongated styloid process. Oral surg oral med oral pathol 1986; 61:399404.

[11]. Steinmann ep. Styloid syndrome in absence of an elongated process. acta otolaryngol 1968; 66:34756.

[12]. Eagle WW. Symptomatic elongated styloid process; report of two cases of styloid process-carotid artery syndrome with operation. Arch Otolaryngol. 1949;49:490-503. [PubMed]

[13]. Casale M, Rinaldi V, Quattrocchi C, Bressi F, Vincenzi $B$,Santini $D$, et al. atypical chronic head and neck pain: don't forget eagle's syndrome. eur rev med pharmacol sci 2008, mar-apr; 12(2):131-33.

[14]. Kaufman Sm, Elzay Rp, Irish Ef. Styloid process variation. Radiologic and clinical study. arch otolaryngol 1970;91:460-63.

[15]. Langlais R. P., Miles D. A., Van Dis M. L. Elongated and mineralized stylohyoid ligament complex: a proposed classification and report of a case of eagle's syndrome. Oral surgery, oral medicine, oral pathology. 1986;61(5):527-532. doi: 10.1016/00304220(86)90400-7. [pubmed] [cross ref]
[16]. Winkler s., sammartino f. j., sr., sammartino f. j., jr., monari j. h. stylohyoid syndrome. Report of a case. Oral surgery, oral medicine, oral pathology. 1981;51(2):215-217. doi: 10.1016/00304220(81)90043-8. [pubmed] [cross ref]

[17]. Kawai T., Shimozato K., Ochiai S. Elongated styloid process as a cause of difficult intubation. Journal of oral and maxillofacial surgery. 1990; 48(11):1225-1228. doi: 10.1016/02782391(90)90544-c. [pubmed] [cross ref]

[18]. Ghafari R, Dalili Z, Abdolahpur S. A study on the frequency of elongated styloid process and eagle's syndrome among patients admitted to guilan dental school clinic (2005-2006) j isfahan dent sch. 2010;6:108-15.

[19]. Scaf G, Freitas Dq, Loffredo Lde C. Diagnostic reproducibility of the elongated styloid process. J appl oral sci. 2003;11:120-4. [pubmed]

[20]. Okabe S, Morimoto Y, Ansai T, Yamada K, Tanaka T, Awano $S$, et al. clinical significance and variation of the advanced calcified stylohyoid complex detected by panoramic radiographs among 80 -yearold subjects. dentomaxillofac radiol. 2006;35:1919. [pubmed]

[21]. Correll rw, jensen jl, taylor jb, rhyne rr. Mineralization of the stylohyoid-stylomandibular ligament complex. A radiographic incidence study. Oral surg oral med oral pathol. 1979;48:286-91. [pubmed]

[22]. Keur jj, campbell jp, mccarthy jf, ralph wj. The clinical significance of the elongated styloid process. Oral surg oral med oral pathol. 1986;61:399-404. [pubmed]

[23]. Mohammed Asif Shaik, Naheeda, Sultan Mohammed Kaleem, Abdul Wahab, and Shahul Hameed, Prevalence of elongated styloid process in Saudi population of Aseer region: Eur J Dent. 2013 OctDec;7(4):449-454.

[24]. Bozkir mg, boga $h$, dere $f$. the evaluation of elongated styloid process in panoramic radiographs in edentulous patients. J med sci. 1999;29:481-5.

[25]. Ilgüy $m$, ilgüy $d$, güler $n$, bayirli g. incidence of the type and calcification patterns in patients with elongated styloid process. J int med res. 2005;33:96102. [pubmed]

[26]. Sachin patil, morphometric study of the styloid process of temporal bone: j clin diagn res. 2014 sep;8(9):ac04-ac06

[27]. Okabe $s$, morimoto $y$, ansai $t$, yamada $k$, tanaka $t$, awano $s$, et al. clinical significance and variation of the advanced calcified stylohyoid complex detected by panoramic radiographs among 80 -yearold subjects. dentomaxillofac radiol. 2006;35:1919. [pubmed]

How to cite this article:

Supriya Garapati, Ch. Santhi, Pentyala Suneetha THE SYLOID PROCESS: MORPHOMETRY AND ITS CLINICAL IMPLICATIONS IN COSTAL REGION OF ANDRAPRADESH, INDIA.Int J Anat Res 2017;5(2.2):3796-3799. DOI: 10.16965/ijar.2017.181 